\title{
Energy Efficiency and Distributed Generation: Case Study
}

\author{
${ }^{1,2}$ A. F. Ferreira, ${ }^{1}$ J. L. Domingos, ${ }^{2}$ T. P. Sousa, ${ }^{2}$ M. L. S. Miguel, ${ }^{2}$ P. H. Franco, ${ }^{1}$ E. G. Domingues, ${ }^{1}$ A. J. Alves, \\ ${ }^{1}$ W. P. Calixto \\ ${ }^{1}$ Graduate Program in Sustainable Process Technology \\ Federal Institute of Education, Science and Technology of Goiás (IFG) \\ Goiânia-GO, Brasil \\ ${ }^{2}$ CELG Distribution - Goiás, Brasil
}

\begin{abstract}
e-mail: adriano.ff@celg.com.br, jose.domingos@ifg.edu.br, marcio.lsm@celg.com.br, tiago.ps@celg.com.br, phfranco@ hotmail.com, eldergd@uol.com.br, aylton.alves@ifg.edu.br, wpcalixto@ieee.org
\end{abstract}

\begin{abstract}
.
The challenges and opportunities of the Brazilian electric sector show the necessity of the diversification of the energy matrix with other renewable energy sources, to attend the growing demand and improving energy security. In this context, energy efficiency and distributed generation represent an important purpose to meet the challenges related to the growing consumption of electricity in Brazil and to mitigate its impacts. The emphasis given in this work is the preparation of a project of energy efficiency with the implementation of a photovoltaic plant in a teaching and research institution, subject to the guidelines established by the National Electric Energy Agency - ANEEL. The results show that the energy saved and the reduction in peak demand, as well as the installation of the photovoltaic plant, will make the facility self-sufficient and result too improvement in the power quality parameters.
\end{abstract}

\section{Key words}

Energy Efficiency, Distributed Generation, Photovoltaic Generation, Power Quality.

\section{Introduction}

The challenges and opportunities of the Brazilian electric sector, heavily dependent on hydropower (66\%) and thermal $(29 \%)$, whose current scenario of fall in reservoir levels and the systematic drive of thermoelectric plants powered by fuel oil, coal and/or natural gas, show the necessity for diversification of the energy matrix with other renewable energy sources. This strategy will collaborate with the growing demand, improving the energy security and reduce emissions of greenhouse gases.

According Kitta Eitler [1], Energy Efficiency is not just a technical issue, because it depends not only of technological advancement. In fact, it also involves the human and social aspects of energy utilization. The human aspect aims to reduce the waste of electricity and to spread the good spending habits among citizens. The technological side, in turn, aims at the development and adoption of more efficient technologies.

Other aspect to observe is the distributed generation that represents the power generation located close to the final consumer, whose installation aims to attend this priority, and yet can generate marketable surplus energy beyond the end user facilities. Another point to highlight is the power generation as a whole, covering electricity and other energies. Together, these alternatives contribute an important part to attend the electricity demand in the country.

\section{Purpose of the survey}

The purpose of this article is to make a critical analysis of energy efficiency project (case study) under the Energy Efficiency Program of the National Electric Energy Agency - PROPEE/ANEEL, Brazil, according to Law No. 9991 of 24 July 2000, as well as ANEEL Normative Resolution No. 482/2012 laying down the general conditions of the micro and mini generation access to power distribution systems, power compensation system, among others [2-3-4].

\subsection{Specific purposes of the survey}

$\checkmark$ Analyze and propose changes in the current legislation on the Energy Efficiency Programs and Distributed Generation (micro and mini generation distributed);

$\checkmark \quad$ Prepare an energy efficiency project integrated to a photovoltaic plant in a teaching and research institution, subject to the guidelines established by ANEEL for its development;

$\checkmark$ Propose new lines of action for the state government on energy efficiency and distributed generation, in addition to create new projects to the area of Concession CELG Distribution, considering the requirement of investment and current energy scenario of the country.

\section{Case Study}

The project as a case study will be applied to the Federal Institute of Education, Science and Technology of Goiás IFG Campus Goiânia, which is a consumer framed in "public authorities" category. This work will evaluate the importance and the technical and economic viability of actions to decrease the waste of electricity and improving the energy efficiency of equipments, processes and end- 
uses of energy as well as evaluate the energy and environmental gains through the installation of a photovoltaic plant on the flat roofs of the consumer.

\subsection{Project Stage}

\subsection{1 - Step 1 - Electrical Installation Diagnosis}

The project includes a preliminary assessment for the implementation of energy efficiency action and additionally the installation of a photovoltaic plant on the flat roofs of the IFG Campus Goiânia. The previous report contains a detailed description of each energy efficiency action and its implementation, the amount of investment, energy efficiency, demand reduction at the tip, feasibility analysis, measurement strategy and verification to be adopted, as well as analysis of the results of studies for the implementation of photovoltaic plant.

Aspects of power quality from measurements made by the local power distributor is analyzed, covering the following parameters: voltage (V); current (A); frequency $(\mathrm{Hz})$; power factor; active power (W); reactive power (VAR); apparent power (VA); total harmonic distortion of voltage (THDV); total harmonic distortion of current (THDI); harmonic components of voltage and current; and sag or swell.

\subsection{2 - Step 2 - Energy Efficiency and Plant Photovoltaic Installation}

This stage is the implementation of the project of energy efficiency in IFG Campus Goiânia, as defined preliminarily, involving the replacement or improvement of the energy performance of equipments and use of energy systems.

A technical and economic feasibility analysis to installation of a photovoltaic plant was conducted by (PELLAGIO) [5]. The results and general data are presented in Table I. May be note and highlight the ability of annual generation of the $790 \mathrm{MWh}$ that corresponds to $96 \%$ of consumption of the installation in 2015. The association of the plant with the energy efficiency project results in a new consumer profile and hiring energy supply and demand. These benefits may redirect to other consumer units, as shown in Figure 1 [Brazilian Association of Distributed Generation].

Table I - Photovoltaic plant data

\begin{tabular}{|l|c|}
\hline Technology & $\mathrm{m}-\mathrm{Si}$ \\
\hline Manufacturer & LG \\
\hline Model & LG255S1C \\
\hline Area $\left(\mathrm{m}^{2}\right)$ & 1.6 \\
\hline Temperature Coefficient $\left(\% /{ }^{\circ} \mathrm{C}\right)$ & 0.47 \\
\hline Efficiency STC $(\%)$ & 16 \\
\hline Efficiency NOCT $(\%)$ & 14.5 \\
\hline Number of modules & 1769 \\
\hline Power $(\mathrm{kWp})$ & 451.02 \\
\hline Annual Generation $(\mathrm{kWh})$ & 790.09 \\
\hline
\end{tabular}

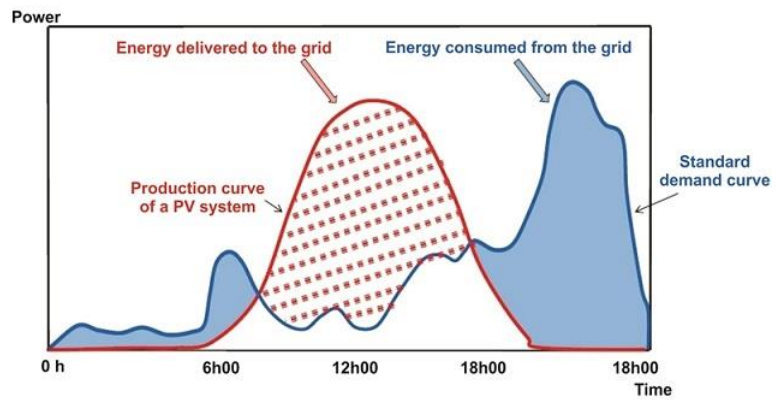

Fig. 1 - Net Mettering - Normative Resolution No. 482/2012

\subsection{3 - Step 3 - Analysis of available data}

To prepare the energy efficiency project were collected data about the lighting systems, air conditioning and power systems. The building consists of eight blocks and common areas as shown in Figure 2. The tables II and III summarize the collected data.

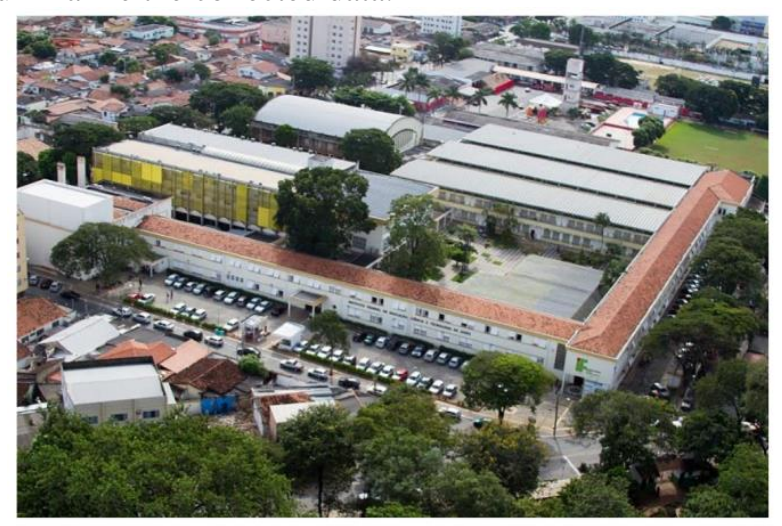

Fig. 2 - IFG Campus Goiânia

Table II - Summary of loads quantity

\begin{tabular}{|c|c|c|c|}
\hline Blocks & $\begin{array}{c}\text { Number } \\
\text { of lamps } \\
\text { (unit) }\end{array}$ & $\begin{array}{c}\text { Number of } \\
\text { ventilators } \\
\text { (unit) }\end{array}$ & $\begin{array}{c}\text { Number of air } \\
\text { conditioning } \\
\text { equipments } \\
\text { (unit) }\end{array}$ \\
\hline Common area & 1185 & 27 & 19 \\
\hline Block 100 & 1047 & 34 & 16 \\
\hline Block 200 & 1204 & 28 & 22 \\
\hline Block 300 & 837 & 32 & 29 \\
\hline Block 400 & 600 & 27 & 24 \\
\hline Block 500 & 754 & 32 & 16 \\
\hline Block 600 & 264 & 2 & 30 \\
\hline Block 700 & 449 & 7 & 21 \\
\hline Block 800 & 340 & 9 & 27 \\
\hline TOTAL & $\mathbf{6 6 8 0}$ & $\mathbf{1 9 8}$ & $\mathbf{2 0 4}$ \\
\hline
\end{tabular}

Table III - Summary of power loads $(\mathrm{kW})$

\begin{tabular}{|c|c|c|c|}
\hline Blocks & $\begin{array}{c}\text { Total } \\
\text { power of } \\
\text { the } \\
\text { lamps }\end{array}$ & $\begin{array}{c}\text { Total } \\
\text { power of } \\
\text { the } \\
\text { ventilators }\end{array}$ & $\begin{array}{c}\text { Total power of } \\
\text { the air } \\
\text { conditioning } \\
\text { equipments }\end{array}$ \\
\hline Common area & 84.65 & 4.82 & 61.14 \\
\hline Block 100 & 36.76 & 5.58 & 56.08 \\
\hline Block 200 & 50.30 & 5.57 & 31.58 \\
\hline Block 300 & 31.05 & 4.96 & 73.8 \\
\hline Block 400 & 23.70 & 4.25 & 49.2 \\
\hline Block 500 & 32.44 & 5.02 & 30.35 \\
\hline Block 600 & 9.14 & 0.4 & 55 \\
\hline Block 700 & 18.67 & 1.4 & 35.31 \\
\hline Block 800 & 14.28 & 1.71 & 71.8 \\
\hline TOTAL & $\mathbf{3 0 0 . 9 9}$ & $\mathbf{3 3 . 7 1}$ & $\mathbf{4 6 4 . 2 5}$ \\
\hline
\end{tabular}




\subsection{4 - Calculation Methodology of Lighting System}

The calculation of the estimate of the coincidence factor in tip (FCP) that represents the lighting loads which are simultaneously used at that time may be obtained by

$$
F C P=\frac{n m \times n d \times n u p}{792}
$$

In equation (1) $\mathrm{nm}$ is the number of months trhoughout the year, for use in peak hours ( $\leq 12$ months); nd represents the number of days throughout the month of use in peak hours ( $\leq 22$ days); nup are the hours of use in peak hours ( $\leq 3$ hours); and 792 is the number of peak hours available over 1 year.

Once obtained the $F C P$, the energy reduction in peak demand can be calculated by

$$
R D P=\left[\begin{array}{c}
\sum_{\text {Sistema } i}\left(q a_{i} \times p a_{i} \times F C P a_{i}\right)-\cdots \\
\cdots \sum_{\text {Sistema } i}\left(q p_{i} \times p p_{i} \times F C P p_{i}\right)
\end{array}\right]
$$

In equation (2) $R D P$ corresponds the reduction in peak demand $(\mathrm{kW}) ; F C P a i$ is the coincidence factor on the tip in the current system $i$; and FCPpi represents the coincidence factor on the tip in system proposed $i$. The result obtained from the equation (2) is important in the analysis of the cost-benefit of energy efficiency project.

The project also contributes to energy saving, which is obtained from the difference between the amount of energy the current system and the improved system and is expressed as

$$
E E=\left[\begin{array}{c}
\sum_{\text {Sistemai }}\left(q a_{i} \times p a_{i} \times h a_{i}\right) \ldots \\
\ldots-\sum_{\text {Sistema } i}\left(q p_{i} \times p p_{i} \times h p_{i}\right)
\end{array}\right] \times 10^{-6}
$$

In equation (3), $E E$ is the energy savings (MWh/year); $q a_{i}$ is the number of lamps in the current system $i ; p a_{i}$ is the lamp and ballast power in the current system $i(\mathrm{~W}) ; h a_{i}$ corresponds to the operation time of the current system $i$ (h/year); $q p_{i}$ is the number of lamps in the proposed system $i ; p p_{i}$ is the lamp and ballast power in the proposed system $i$ (W); $h p_{i}$ is the operation time of the proposed system $i$ (h/year).

For the calculations are considered 6544 the total of 6680 lamps, since some lamps are already efficient. Table IV below shows the total number of lamps to be replaced and

\begin{tabular}{|c|c|c|c|c|c|c|c|}
\hline \multicolumn{4}{|c|}{ Current Equipment } & \multicolumn{4}{|c|}{ Efficient Equipment } \\
\hline Description & $\begin{array}{c}\text { Nominal } \\
\text { wattage } \\
(\mathrm{W})\end{array}$ & $\begin{array}{c}\text { Number } \\
\text { of lamps } \\
\text { (unit) }\end{array}$ & $\begin{array}{l}\text { Demand } \\
(\mathrm{kW})\end{array}$ & Description & $\begin{array}{c}\text { Nominal } \\
\text { wattage } \\
(\mathrm{W})\end{array}$ & $\begin{array}{c}\text { Number } \\
\text { of lamps } \\
\text { (unit) }\end{array}$ & $\begin{array}{l}\text { Demand } \\
(\mathrm{kW})\end{array}$ \\
\hline Compact Fluorescent Lamp - CFL & 9 & 40 & 0.36 & \multirow{2}{*}{$\begin{array}{l}\text { Bulb LED } \\
\text { Lamp }\end{array}$} & \multirow{2}{*}{7} & \multirow{2}{*}{77} & \multirow{2}{*}{0.54} \\
\hline Incandescent Lamp & 25 & 37 & 0.93 & & & & \\
\hline Incandescent Lamp & 50 & 64 & 3.2 & \multirow{3}{*}{$\begin{array}{l}\text { Bulb LED } \\
\text { Lamp }\end{array}$} & \multirow{3}{*}{9.5} & \multirow{3}{*}{195} & \multirow{3}{*}{1.85} \\
\hline Incandescent Lamp & 60 & 37 & 2.22 & & & & \\
\hline Compact Fluorescent Lamp - CFL & 18 & 94 & 1.69 & & & & \\
\hline Compact Fluorescent Lamp - CFL & 26 & 172 & 4.47 & $\begin{array}{l}\text { Bulb LED } \\
\text { Lamp }\end{array}$ & 13 & 172 & 2.24 \\
\hline Tubular Fluorescent Lamp + Reactor & 16.8 & 117 & 1.97 & \multirow{2}{*}{$\begin{array}{c}\text { Tubular } \\
\text { LED Lamp }\end{array}$} & \multirow{2}{*}{11} & \multirow{2}{*}{256} & \multirow{2}{*}{2.82} \\
\hline Tubular Fluorescent Lamp + Reactor & 21 & 139 & 2.92 & & & & \\
\hline Tubular Fluorescent Lamp + Reactor & 29.4 & 316 & 9.29 & \multirow{3}{*}{$\begin{array}{l}\text { Tubular } \\
\text { LED Lamp }\end{array}$} & \multirow{3}{*}{21} & \multirow{3}{*}{5844} & \multirow{3}{*}{122.72} \\
\hline Tubular Fluorescent Lamp + Reactor & 33.6 & 1278 & 42.94 & & & & \\
\hline Tubular Fluorescent Lamp + Reactor & 42 & 4250 & 178.5 & & & & \\
\hline \multicolumn{2}{|l|}{ Total } & 6544 & 248.48 & \multicolumn{2}{|c|}{ Total } & 6544 & 130.17 \\
\hline
\end{tabular}
by what type.

Table IV - Equivalence table used - Lighting system

\begin{tabular}{|c|c|c|c|c|c|c|c|c|c|}
\hline \multicolumn{5}{|c|}{ Current Equipment } & \multicolumn{5}{|c|}{ Efficient Equipment } \\
\hline Description & $\begin{array}{l}\text { Cooling } \\
\text { Capacity } \\
\text { (BTU/h) }\end{array}$ & Wattage (W) & Unit & Demand $(\mathrm{kW})$ & Description & $\begin{array}{l}\text { Cooling } \\
\text { Capacity } \\
\text { (BTU/h) }\end{array}$ & $\begin{array}{l}\text { Wattage } \\
\text { (W) }\end{array}$ & Unit & $\begin{array}{c}\text { Demand } \\
(\mathrm{kW})\end{array}$ \\
\hline Window. air cond. & 10000 & 1200 & 6 & 7.2 & \multirow{5}{*}{$\begin{array}{l}\text { Split air cond. - } \\
\text { Smart Inverter }\end{array}$} & \multirow{5}{*}{900} & \multirow{5}{*}{790} & \multirow{5}{*}{18} & \multirow{5}{*}{14.22} \\
\hline Split air cond. & 7000 & 730 & 2 & 1.46 & & & & & \\
\hline Split air cond. & 9000 & 822 & 1 & 0.822 & & & & & \\
\hline Split air cond. & 9000 & 900 & 3 & 2.7 & & & & & \\
\hline Split air cond. & 9000 & 824 & 6 & 4.94 & & & & & \\
\hline Window. air cond. & 12000 & 1300 & 14 & 18.2 & \multirow{6}{*}{$\begin{array}{l}\text { Split air cond. - } \\
\text { Smart Inverter }\end{array}$} & \multirow{6}{*}{12000} & \multirow{6}{*}{1080} & \multirow{6}{*}{76} & \multirow{6}{*}{82.08} \\
\hline Split air cond. & 12000 & 1065 & 1 & 1.07 & & & & & \\
\hline Split air cond. & 12000 & 1070 & 5 & 5.35 & & & & & \\
\hline Split air cond. & 12000 & 1200 & 10 & 12.00 & & & & & \\
\hline Split air cond. & 12000 & 1300 & 45 & 58.5 & & & & & \\
\hline Split air cond. & 12000 & 1168 & 1 & 1.17 & & & & & \\
\hline
\end{tabular}

Table V - Equivalence table used - Air-conditioning system 
Table V - Equivalence table used - Air-conditioning system - continuation

\begin{tabular}{|c|c|c|c|c|c|c|c|c|c|}
\hline \multicolumn{5}{|c|}{ Current Equipment } & \multicolumn{5}{|c|}{ Efficient Equipment } \\
\hline Description & $\begin{array}{l}\text { Cooling } \\
\text { Capacity } \\
\text { (BTU/h) }\end{array}$ & Wattage $(\mathrm{W})$ & Unit & Demand $(\mathrm{kW})$ & Description & $\begin{array}{l}\text { Cooling } \\
\text { Capacity } \\
\text { (BTU/h) }\end{array}$ & $\begin{array}{l}\text { Wattage } \\
\text { (W) }\end{array}$ & Unit & $\begin{array}{l}\text { Demand } \\
(\mathrm{kW})\end{array}$ \\
\hline Window. air cond. & 18000 & 1800 & 1 & 1.8 & \multirow{3}{*}{$\begin{array}{l}\text { Split air cond. - } \\
\text { Smart Inverter }\end{array}$} & \multirow{3}{*}{18000} & \multirow{3}{*}{1514} & \multirow{3}{*}{11} & \multirow{3}{*}{16.65} \\
\hline Split air cond. & 18000 & 1755 & 1 & 1.75 & & & & & \\
\hline Split air cond. & 18000 & 1800 & 9 & 16.2 & & & & & \\
\hline Split air cond. & 24000 & 2420 & 1 & 2.42 & \multirow{2}{*}{$\begin{array}{l}\text { Split air cond. - } \\
\text { Smart Inverter }\end{array}$} & \multirow{2}{*}{24000} & \multirow{2}{*}{2130} & \multirow{2}{*}{49} & \multirow{2}{*}{104.37} \\
\hline Split air cond. & 24000 & 2500 & 48 & 120 & & & & & \\
\hline Split air cond. & 27000 & 2720 & 1 & 2.72 & \multirow{2}{*}{$\begin{array}{l}\text { Split air cond. - } \\
\text { High Wall } \\
\text { Inverter }\end{array}$} & \multirow[b]{2}{*}{27000} & \multirow[b]{2}{*}{2600} & \multirow[b]{2}{*}{3} & \multirow[b]{2}{*}{7.8} \\
\hline Split air cond. & 30000 & 3200 & 2 & 6.4 & & & & & \\
\hline Split air cond. & 36000 & 3800 & 1 & 3.8 & \multirow{2}{*}{$\begin{array}{l}\text { Split air cond. - } \\
\text { Smart Inverter }\end{array}$} & \multirow{2}{*}{18000} & \multirow{2}{*}{1514} & \multirow{2}{*}{40} & \multirow{2}{*}{60.56} \\
\hline Split air cond. & 36000 & 4200 & 19 & 79.8 & & & & & \\
\hline Cassette air cond. & 36000 & 4200 & 2 & 8.4 & $\begin{array}{c}\text { Cassette air } \\
\text { cond. - Inverter }\end{array}$ & 36000 & 2866 & 2 & 5.73 \\
\hline \multicolumn{3}{|c|}{ Total } & 179 & 356.70 & \multicolumn{3}{|c|}{ Total } & 199 & 291.42 \\
\hline
\end{tabular}

\subsection{5 - Calculation Methodology of Air-conditioning system}

The benefits to be obtained from the project taking into account the air conditioning systems follow the same procedures used in lighting systems. Thus the demand for reduction in tip time is obtained from

$$
R D P=\left[\sum_{\text {Sistema } i}\left(\begin{array}{c}
q a_{i} \times P u a_{i} \times F C P a_{i}-q p_{i} \times \ldots \\
\ldots P u p_{i} \times F C P p_{i}
\end{array}\right)\right]
$$

In equation (4), $R D P$ corresponds to the reduction in tip demand $(\mathrm{kW}) ; F C P a_{i}$ is the coincidence factor on the tip in the current system $i ; F C P p_{i}$ is the coincidence factor on the tip in system proposed $i$.

Thus, the energy saving is obtained by

$$
E E=\left[\sum_{\text {Sistema } i}\left(\begin{array}{c}
q a_{i} \times P u a_{i} \times h a_{i}-q p_{i} \\
\times P u p_{i} \times h p_{i}
\end{array}\right)\right] \times 10^{-3}
$$

In equation (5), $q a_{i}$ represents the amount of apparatus in the current system $i ; P u a_{i}$ is the average power of the apparatus on the current system $i(\mathrm{~kW}) ; h a_{i}$ corresponds to the operation time of the current system $i$ (h/year); $q p_{i}$ represents the number of devices in the proposed system $i$; Pup $i$ is the average power of the apparatus of the proposed system $i(\mathrm{~kW}) ; h p_{i}$ is the operation time of the proposed system $i$ (h/year).

For the calculations are considered 179 of the total of 204 equipments raised during the energy diagnosis, once some are already efficient. The Table $\mathrm{V}$ shows the total air conditioners to be replaced and by what type.

\subsubsection{Cost-Benefit Relation - RCB}

The economic feasibility analysis of the energy efficiency projects, as Module 7 PROPEE ANEEL, provides for the calculation and analysis of annual costs and benefits and must meet a feasibility condition for it to be implemented properly [xx].

Thus, the annual cost $\left(C A_{T}\right)$ is calculated using

$$
C A_{T}=\sum_{n} C A_{n}
$$

where $C A_{n}$ corresponds to anual costs of each equipment ( $\mathrm{R} \$ /$ year) and is obtained by

$$
C A_{n}=C E_{n} \times \frac{C T}{C E_{T}} \times F R C_{u}
$$

In equation (7) $C E_{n}$ is the cost of each equipment (R\$); $C T$ is the total project cost $(\mathrm{R} \$) ; F R C_{u}$ is the capital recovery factor for $u$ years (1/year); $u$ corresponds to useful life of the equipments (years); $C E_{T}$ is the total cost of equipments $(\mathrm{R} \$)$, and is given by

$$
C E_{T}=\sum_{n} C E_{n}
$$

The capital recovery factor takes into account the discount rate $i$ (1/year) and the useful life of the equipments, and relates these quantities through

$$
F R C_{u}=\frac{i \times(1+i)^{u}}{(1+i)^{u}-1}
$$

The calculation of benefits should be evaluated on the point of view of the electric power system by assigning monetary value to energy savings and demand reduction by the system tariff. Thus the annual benefit $\left(B A_{T}\right)$ ( $\mathrm{R} \$$ /year) is calculated by

$$
B A_{T}=\frac{E E \times C E E}{R D P \times C E D}
$$

In equation (10) $C E E$ corresponds to the unit cost of energy saved (R $\$ / \mathrm{MWh}) ; C E D$ equals the unit cost of avoided demand $(\mathrm{R} \$ / \mathrm{kW}$ year). The tariff values at the date of preparation of this project are shown in ANEEL Ratifying Resolution No. 1.858, of February 27, 2015, and assume $C E E=308.08 \mathrm{R} \$ / \mathrm{MWh}, C E D=389.13$ $\mathrm{R} \$ / \mathrm{kW}$ year.

If the project has more than one system (lighting, refrigeration, etc.) each of these end uses must have its $R C B$ calculated. It should also be introduced to $R C B$ of global project, considering the sums of the costs and benefits. The calculation of Cost-Benefit $R C B$ relationship is then obtained by 


$$
R C B=\frac{C A_{T}}{B A_{T}}
$$

For energy efficiency projects that include a photovoltaic plant in the consumer unit, the cost-benefit ratio $R C B$ should be less than or equal to 0.8 to be considered economically viable. The calculation of the $R C B$ of the total project will be calculeted with the relationship

$$
R C B=\frac{C A_{T}}{B A_{C G}+B A_{E E}}
$$

In (12) equation $B A_{C G}$ is an annual benefit of generating plant (R \$/year).

From the presented so far, the results are summarized in Table VI, considering the $R C B$ for each system and the $R C B$ of the total project. For these reasons it is noticeable the contribution of each project system, where there are the contributions of the lighting system and photovoltaic plant to the system efficiency, where is clear that the benefits outweigh the costs.

It is also appropriate to state that the improvement in the legislation of these programs is needed, since the greatest amount of resources $(60 \%)$ is for consumers classified as low-income and these account for only $4 \%$ of total electricity consumption in Brazil.

Still one has to consider that the Normative Resolution 482 from ANEEL, which deals with micro and minigeneration distributed in Brazil and created the compensation system (Net Metering) was updated in November 2015. With the proposed updates, projections indicate the possibility of in the 2023 scenario, the country record 702,000 connections, totaling $2.6 \mathrm{GW}$ in installed capacity of distributed generation. Despite the potential and promising scenarios, the review of the resolution 482 is just the beginning of this process. There are difficulties that limit the expansion of distributed generation and are necessary regulatory and tax incentives such as the reduction of equipment import fees and taxes levied in the electricity generation. If added the factors and macroeconomic and energy scenarios of Brazil today, the challenges for the consolidation of distributed generation become somewhat uncertain.

\subsection{7 - Power Quality Measurement}

During the last fifteen days of October month it was held the power quality measurement delivered by the power distributor. The electrical parameters measured were the voltage, current, total harmonic distortion voltage, rate of harmonic current distortion, active power, reactive power and apparent power, corresponding to Figure 1-8, respectively.

Table VI - Cost - Benefit Relation

\begin{tabular}{|l|r|r|r|}
\hline \multicolumn{1}{|c|}{ System } & $\begin{array}{c}\text { Annualized } \\
\text { Cost (R\$) }\end{array}$ & $\begin{array}{c}\text { Annualized } \\
\text { Benefits } \\
(\mathbf{R} \$)\end{array}$ & $\begin{array}{c}\text { Cost } \\
\text { Benefit } \\
\text { Relation }\end{array}$ \\
\hline Lighting & 67150.81 & 132646.29 & 0.51 \\
\hline Air Conditioning & 69068.76 & 66568.01 & 1.04 \\
\hline Photovoltaic Plant & 317199.48 & 448574.43 & 0.71 \\
\hline Total & $\mathbf{4 5 3 4 1 9 . 0 5}$ & $\mathbf{6 4 7 7 8 8 . 7 3}$ & $\mathbf{0 . 7}$ \\
\hline
\end{tabular}

The quality parameters used to measure the analysis follow the Brazilian regulation entitled "Electricity Distribution Procedures in the National Electric System PRODIST Module 8 - Electric Power Quality" [6], as shown in Tables VII and VIII.

Table VII - Tracks Classification Voltage

\begin{tabular}{|c|c|}
\hline Supply Voltage & $\begin{array}{c}\text { Variation range reading } \\
\text { voltage (TL) in relation to the } \\
\text { reference voltage (TR) }\end{array}$ \\
\hline Adequate & $0,93 \mathrm{TR} \leq \mathrm{TL} \leq 1,05 \mathrm{TR}$ \\
\hline Precarious & $0,90 \mathrm{TR} \leq \mathrm{TL}<0,93 \mathrm{TR}$ \\
\hline Critical & $\mathrm{TL}<0,90 \mathrm{TR}$ ou $\mathrm{TL}>1,05 \mathrm{TR}$ \\
\hline
\end{tabular}

Table VIII - Global Reference values of Total Harmonic Distortion

\begin{tabular}{|c|c|}
\hline \multicolumn{2}{|c}{ Distortion } \\
\hline Nominal Voltage & $\begin{array}{c}\text { Total harmonic distortion } \\
\text { voltage (THD) [\%] }\end{array}$ \\
\hline$V_{N} \leq 1 K V$ & 10 \\
\hline $1 K V<V_{N} \leq 13,8 K V$ & 8 \\
\hline $13,8 K V<V_{N} \leq 69 K V$ & 6 \\
\hline $69 K V<V_{N}<230 K V$ & 3 \\
\hline
\end{tabular}

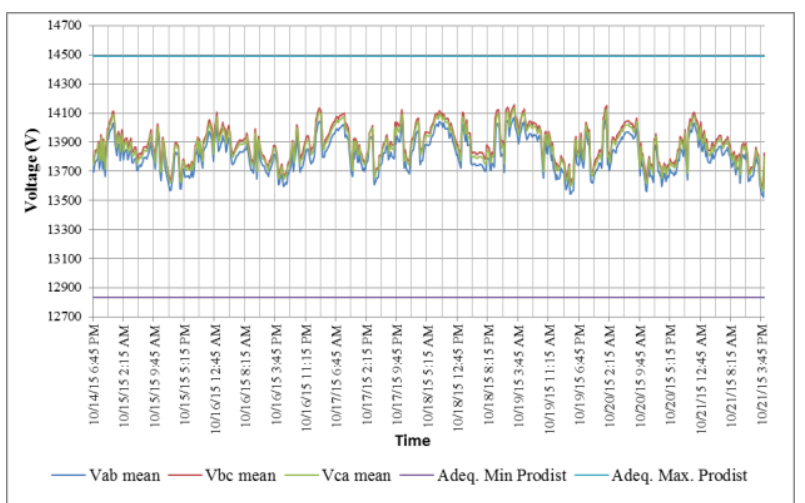

Fig. 3 - Voltage (V)

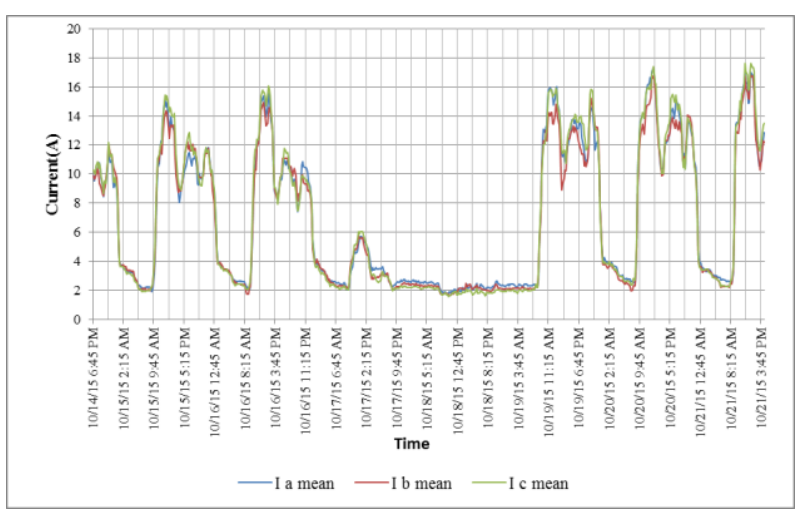

Fig. 4 - Current (A)

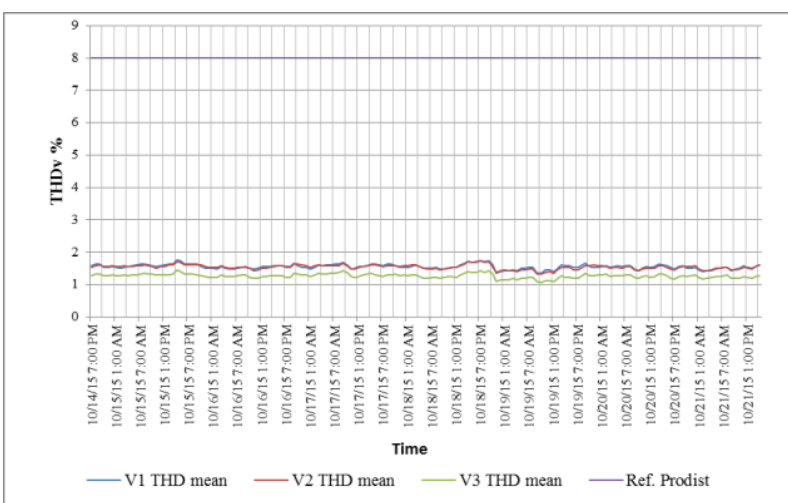

Fig. 5 - Total Harmonic Distortion Voltage (\%) 


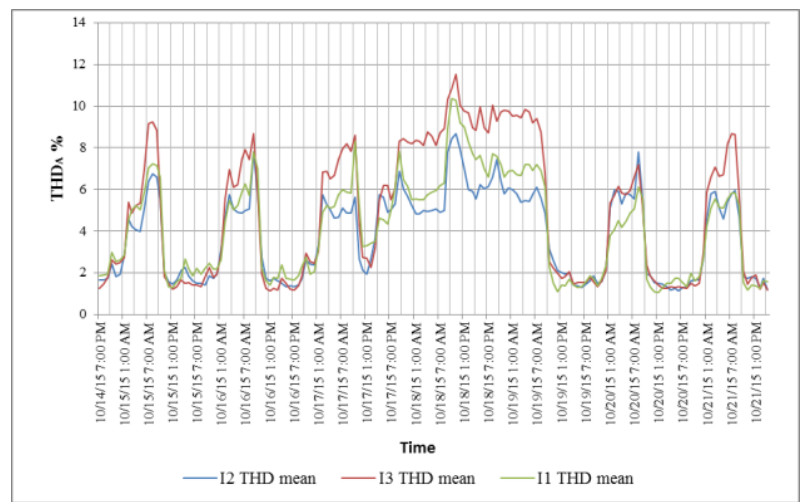

Fig. 6 - Total Harmonic Distortion Current (\%)

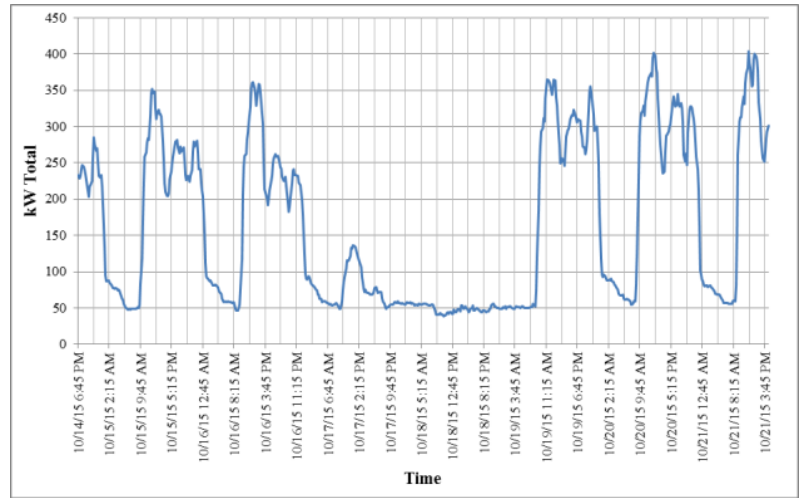

Fig. 7 - Active Power (kW)

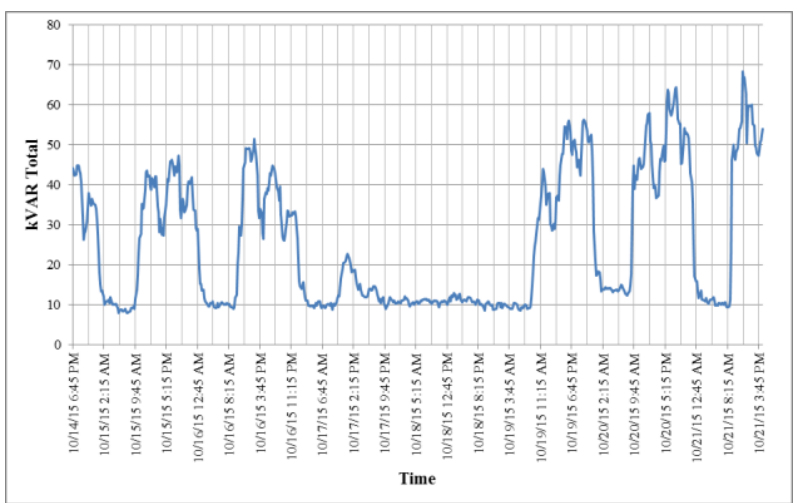

Fig. 8 - Reactive Power (kVAR)

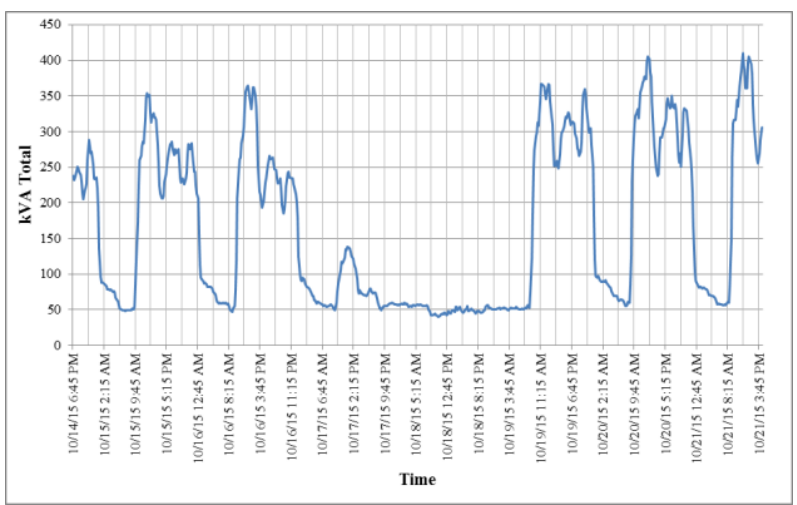

Fig. 9 - Apparent Power (kVA)

As evidenced by the measurement, the recorded voltage levels during the sampling period, presented pursuant to regulation (Module 8 - Power Quality of Electricity Distribution Procedures in the National Electric System - PRODIST). Regarding to the harmonic current distortion (THD) recorded during the measurement an acceptable distortion index was obtained. Similarly, the total voltage harmonic distortion levels (THDV) showed accordance with the standard. Thus, the energy provided by the local concessionaire of energy - CELG D is in conformity with the Brazilian Standardization, from the point of view of voltage levels and the waveform. With the implementation of the project it is expected that the power quality aspects remain within of the limits established by Brazilian regulation.

\section{Conclusion}

This article aims to present the results of the development of an energy efficiency project with the implementation of a photovoltaic plant in a teaching and research institution, subject to the guidelines set by ANEEL for its elaboration.

The results so far lead to the conclusion that energy savings and demand reduction avoided at peak times, provided by the energy efficiency project and the photovoltaic generation, that the installation can to become self-sufficient and indicates the improvement of the power quality parameters.

It is also important to mention that the implementation of this project will serve as a reference for other consumers join to the Energy Efficiency Program, and indicates the need for adequacy of Brazilian legislation to encourage distributed generation of electricity through renewable sources.

\section{References}

[1] KITTA EITLER, VANIA LINS. Energia que Transforma: Rio de Janeiro: FUNDAÇÃO ROBERTO MARINHO, 2012. (IN PORTUGUESE)

[2] ANEEL - Agência Nacional de Energia Elétrica. Programa de Eficiência Energética - Procedimentos do Programa de Eficiência Energética- PROPEE. (IN PORTUGUESE)

[3] BRASIL. Brasil. Lei no 9.991 de 24 de julho de 2000. (IN PORTUGUESE)

[4] ANEEL - Agência Nacional de Energia Elétrica. Resolução Normativa ANEEL n 482/2012. (IN PORTUGUESE)

[5] PELÁGio, P. R. F. S. Estudo de viabilidade técnicoeconômica para implantação de sistema de painéis fotovoltaicos no Campus Goiânia do IFG. 2014. 123 f. Dissertação (Mestrado em Tecnologia de Processos Sustentáveis) - Instituto Federal de Educação, Ciência e Tecnologia de Goiás, Goiânia 2014. (IN PORTUGUESE)

[6] ANEEL - Agência Nacional de Energia Elétrica. Procedimentos de Distribuição de Energia Elétrica no Sistema Elétrico Nacional- PRODIST - Módulo 8. (IN PORTUGUESE) 